\title{
LABOUR MARKET EFFECTS OF PUBLIC WORK: HUNGARY'S EXAMPLE
}

\author{
Cseh-Papp, Imola - Varga, Erika
}

\begin{abstract}
The size of the Hungarian public work programme was an appropriate public policy response across Europe to tackle the crisis and long-term unemployment. Hungary has used the resources available to all labour market tools only for this kind of intervention. Therefore, it is important task to analyse its effectiveness together with the short and longterm impacts. In our study, we are going to undertake a brief overview of Hungarian public work-from the economic-social regime change to the present day by focusing on how efficient the system is and how it can fulfil its purpose. In the course of the analysis we draw parallels between the available international and domestic literature and our own research results in the years 1995, 2005, 2015 and 2017. The results show that although the attempt is appropriate, it has many shortcomings that require correction.
\end{abstract}

Key words: labour market policy, public work, workers, unemployment JEL: I 38; I 39; J 48 


\section{Introduction}

To put it in short, labour market tools are categorized into two groups: the tools that help the life of the unemployed (welfare) and the tools that encourage re-placement (workfare). The welfare policy is based on social solidarity. We use the term "workfare for programmes that require work in return for social assistance. Behind the public work programmes there is the concept of workfare, according to which the provision of benefits and income transfers is worthy of some kind of work for the community. The goal to be achieved through public work and the extent to which it is used determines whether it is an active employment policy tool or a social policy measure to deal with poverty. They are used in countries with different levels of development.

In the practice of developing countries, most of these programmes offer low wages, short-term employment, typically in the construction, agriculture and rural development sectors, in many cases in the most disadvantaged regions and community services (Eardley et al., 1996; Grover-Stewart, 1999; Ismail, 2016). Public works are increasingly being used to fight poverty, to guarantee employment, or to move towards self-employment, such as Argentina, Ethiopia, India, Iran (Shah-Steinberg, 2015; Ismail, 2016; Rosas-Sabarwal, 2016; Karimi, 2018). In many less developed countries, they are almost the only form of labour market intervention.

In developed countries, as a response to mainly short-term economic shocks, or high unemployment, short-term public work programmes are typically employed, primarily to channel the unemployed back into work. Target participants are usually special social groups, so these programmes often include re-employability in combination with training elements (Kim-Zurlo, 2007; Melo, 2009; Robbins, 2015; Guccio et al., 2014; Crost, 2016; Schöb et al., 2016; Bertrand, 2017). In developed countries, the use of public works programmes is retreating because costly and other active labour market interventions have proved to be more effective, mainly due to substitution and displacement effects (Hort, 2001; Zieliński, 2015; Douarin-Mickiewicz 2017; Ko-Cho, 2017).

The extent, targeting and complexity of the Hungarian public work programme experienced in the past have been quite unusual in the practice of developed countries. There are many arguments for and against public employment, and opinions are very divided.

According to research, society supports the principle of „work for help”. Public work tests the ability to work, gives local governments the opportunity to employ labour cost-efficiently, generates long-term employment and continuous income for the families concerned. Public work has become a universal tool for dealing with unemployment and poverty, although it is lagging behind any value that is a condition for minimum living. Yet, in the disadvantaged settlements, the only option is for formal work and livelihood, since the majority of the regions that are heavily involved 
in public work have few jobs. In disadvantaged settlements, local farmers are able to employ the local population that is separated from agricultural activity as part of public work. Municipalities provide the most motivated, experienced, reliable, unemployed under this programme with essentially continuous employment. Public work wages are higher than the amount of job replacement support, somewhat reducing poverty, but not enough to allow an outbreak of poverty (Bujdosó-Remenyik, 2008, HerdonZörög, 2012; Szücs et al. 2013; Czirfusz, 2014; Czibere-Molnár, 2017; Koós, 2016; Uszkai, 2014; Váradi, 2010; Váradi 2016).

At the same time, research on the operation of public work has also shown that its expenditures are displacing the applicability of active tools, and the chances of labour market reintegration are greatly reduced. The wage surcharge of 25,000 HUF between the public work wage and the labour market wage does not motivate to be employed. Thus, most people do not choose hard physical work for the minimum plus income. Supported programmes tend to employ the most hopeless, the most inexperienced unemployed, with a high proportion of Roma. Nearly one third of the participants in the public work programme had received income support and social assistance, i.e. they were unemployed permanently. Thus, the participants do not have the capital required for the primary labour market, either in terms of qualifications, social status, or relationships, nor in terms of work experience. The segregation effect of public work is also well known. One of the reasons for this is that the majority of public employees work in workplaces where all employees are employed by the public. Public work programmes can lead to the closure of a settlement and create competition for local entrepreneurs. It is against public work to stigmatize the participants that they are more likely to seek employment in the framework of the primary labour market. Furthermore, the fact that in many cases the tasks performed are meaningless are demoralizing (Csehné, 2007; CseresGergely-Molnár, 2014; Fazekas, 2015; Frey, 1993; 1995; 1997; 2007; Koltai, 2014; Kulinyi, 2013; László, 2016; Scharle, 2013).

In Hungary, between 30 and 40 thousand people worked in some form of public work from 1996 to 2006. This number increased from 2009 to 60-100 thousand and in 2013 it exceeded 130 thousand. In 2018 the planned number is 190 thousand, in 2019 it is 170 thousand, and in 2020 it is 150 thousand (Figure 1). This value is also high internationally. The country spends a lot on public work programmes in international comparison, and little on other labour market tools that would help the retraining or job seeking of the unemployed. Budget expenditures on public work continued to increase from 2011 to 2016 (from HUF 70 billion to HUF 340 billion), but much lower than in 2018 (HUF 220 billion). 


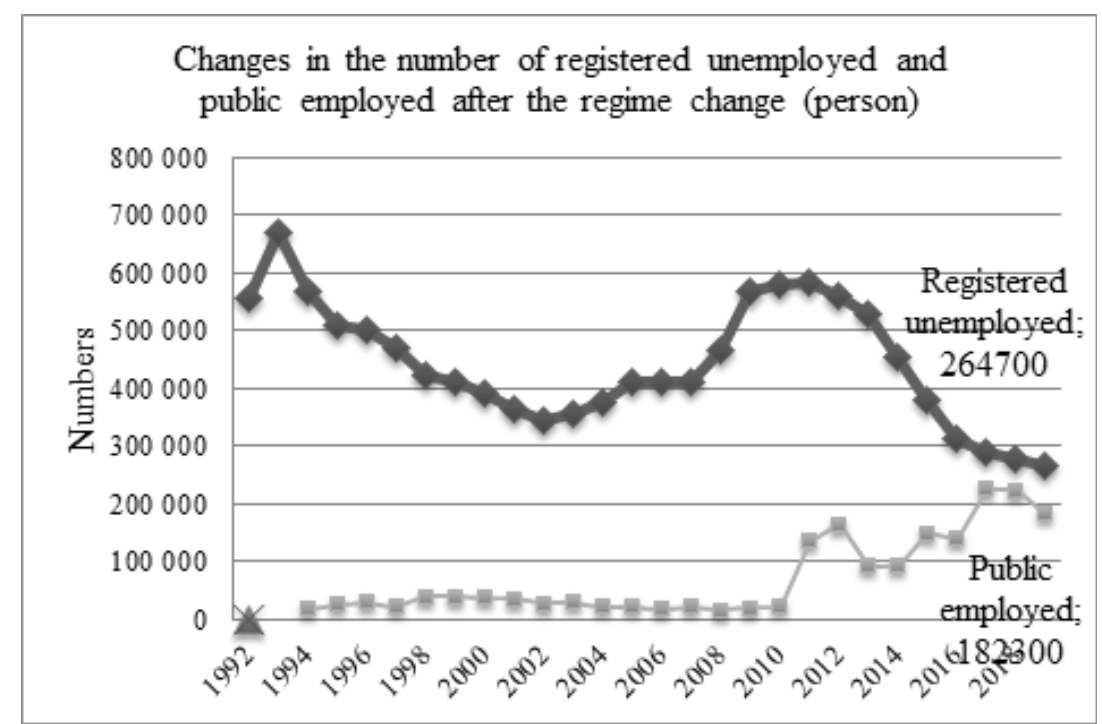

Figure 1 Changes in the number fo registered unemployed and public employed after the change of the regime

Source: authors'own calculation based on CSO

\section{Material and Methods}

The study focuses on the main characteristics of public workers based on the results of a survey carried out at three occasions covering a period of about 20 years. The purpose of the data analysis was to find out how the structural distribution of the unemployed participating in public work changed in a subregion with labour market indicators corresponding to the national average ${ }^{1}$.

The survey sample was made up by public workers (213 persons) at the Hatvan office in 1994, and in 2004 to individuals (122 persons) engaged in public work and participants in programmes launched in 2014 (611 persons). The time of investigations ranges from January-March 1995, January-March 2005 to JanuaryMarch 2015 and related to public workers in the previous calendar year.

1 in: CSEHNÉ PAPP I. (1995): Közhasznú foglalkoztatás a Heves Megyei Munkaügyi Központ Hatvani Kirendeltségén az országos mutatók tükrében, 1994-ben, OMK. Manuscripts, and CSEHNÉ PAPP I. (2007): A közhasznú foglalkoztatás jogi és humán vonatkozású változásai az utóbbi tíz évben, Munkaügyi Szemle. 4. pp. 15-19. 
In the next part of the study, the aim of the survey was to formulate a questionnaire mapping of the opinion of the public employees (103 persons) in 2017.

\section{Results}

\section{Results of data analysis}

The examined period can be divided into two parts. During the first ten years, the number of persons involved in public work decreased to about half. According to a survey carried out in 1995, in 1994, the number of public workers was 213 and in 2004 only 122. This significant reduction in the number of employees was justified by the widening of labour market subsidies. On the other hand, the rate of support provided by the Employment Fund could also have affected the decline in asset penetration. In 1994, the Hatvan Office was able to spend HUF 24,319,000 on public work, and for the year 2004 the available framework changed to HUF $43,431,000$, which represents a significant decrease, including the changes in inflation over ten years. In the second phase, the number of participants was doubled by raising HUF 273,092 million funds in 2015 .

There was a significant change in the gender distribution in both periods: in 1994 , $75 \%$ of public workers and only $42 \%$ in 2004 , and again in 2014, increased to $64 \%$.

The 1995 survey found that most (30\%) public workers completed 8 general and vocational schools; The distribution of public workers by educational level slightly improved in the second period of the study.

The qualification provided a period of shorter working hours before public work in 1994, while this was not typical for 2004 and 2014.

In 1994, almost equal share of public work was paid in annuity and the unemployed receiving the replacement income allowance, in 2004 it was twice the number of regular social assistance recipients of public work, as they became public workers during the annuity period. In 1994, 30\% of those with qualifications were already in public work during the disbursement period, and the unskilled were also $30 \%$ in the period of income replacement support. In 2004, the proportion of the unemployment benefit decreased and the proportion of regular social assistance to those in public work increased. In 2014, 35\% of public employees had not been employed for 1 year other than public work. 2 years $11 \%$, 3 years $32 \%$, 4 years $8 \%$, 5 years $14 \%$ did not work on the primary labour market.

Following public work, the same proportion (19\%) of employees were in 1994 than in 2004, and slightly less (13\%) in 2014.

The analysis of the 1994 data revealed that the younger the public worker, the greater the chances of getting a job. By 2004, the employment prospects for the 
18-25 age group decreased and doubled for those over 51 years of age. By 2014, only $13 \%$ of $18-25$-year-old were able to find a job in the primary labour market, although more than half of public employees would need to work occasionally.

In the first 10 years, there is a stronger correlation between employee qualifications and the level of public work wage, and the proportion of those receiving minimum wage increased (from $52 \%$ to $77 \%$ ).

In 1994, the unemployed were best paid (higher than the minimum wage) who worked for 7-9 months. By 2004, there was no correlation between the duration of employment and the amount of salary received for the performance of public work. Wages have been pushed into the background of public work because clients have made a commitment even if they have not earned high earnings.

In 1994, there was a greater dispersion between the nature of the activity carried out in the framework of public work and the wage received for the performance of public work. In 2004, an amount higher than the minimum wage could only be obtained in the case of auxiliary and intellectual work, and the minimum wage was doubled for intellectual work only.

There was not much change in the nature of the activity performed during the two study periods. Most non-profit workers completed auxiliary work: 35\% in $1994,67 \%$ in $2004,68 \%$ in 2014 . They are mainly workers with primary education. The results of the previous research have shown that public workers have completed activities that correspond to their educational attainment within the framework of public work. The difference is that in 2004 and 2014, 93\% of those with a vocational qualification had semi-skilled jobs. Higher education graduates appeared at every survey time and at all levels of activity.

Based on the research experience, the following common conclusions are interesting:

- The 1995 survey revealed that some respondents had been unemployed several times since the introduction of the register. This was also reflected in the 2005 and 2015 analyses. The reason for this was seen in the first two study periods that employers who used to find a job in the primary labour market were often employed and were permanently marginalized. As a result of a personal interview with several interviewees during the 2015 survey, they found that they were left in the cycle because they had no time to look for a job.

- In the first and second surveys, it has been found that unemployed people who have only been part of public work are more likely to be reintegrated than those who have repeatedly taken part. In 2015, this was rarely the case.

- The majority of jobs offered in the context of public work are low prestige, not suitable for social appreciation or employment without support. In 2015, this statement was complemented by an employee side: most of them 
previously thought it was unimaginable to work in public. Since public work has expanded with national employers, the number of job opportunities has multiplied.

- In 1994 and 2004, the typical public worker worked for 3-6 months, with 8 years spent in education. In 2014, most of the public workers were working in a physical job, with 8 classes, living in modest conditions. Years ago, they kept their family from the dole, casual and black work.

- For the first ten years, wages equivalent of the minimum wage remained the most widespread, while in 2015 , all workers considered the wage to be unfair.

- While in 1994 there was a strong correlation between the nature of the activity performed in the context of public work and the level of unemployment, by 2004 , public work at a lower level of activity was more characteristic. This was also supported by the 2014 data.

- In 1994 and 2004, most of the employers participating in the programme were the mayor's offices, who had been employed for many years. The activities they carried out were of a public nature, and the business sector had little interest and would not have been realized in the absence of support. Most of the employers involved in the 2014 study have been working in public for a long time, usually 2-4 years.

\section{Results of the questionnaire}

The demographic composition of the population receiving public work and its distribution by educational level are much less favourable than those of the registered unemployed; The results of the study have shown that men with 8 classes or lower levels of education are the long-term workers in this form of employment.

$35 \%$ of those surveyed have not been working for a year outside of public work. 2 years $11 \%, 3 \% 32 \%, 4 \% 8$ years, $14 \% 5$ years ago were not present on the primary labour market. Nearly one third of the sample was regularly (more than 4 times) involved in a public work programme. Nearly a third (29\%) of those affected have already worked at their current job several times. Especially for men, they have been repeatedly recruited regularly as a seasonal worker for more than three times. In the case of women, more than three-quarters of those with a profession or a general certificate of secondary education expect to work in public work several times.

According to the data of the given office, $13 \%$ of the unemployed were on the labour market on average after the public work. More than half of the respondents would need to work occasionally. But they cannot find the time or the right job.

Members of the younger generation are more likely to be in the active age than those in the older age group. In the case of the 36-45-year-olds, „parking” and the provision of temporary income are typical. Those over the age of 45 hardly get into the programme, and this active tool is the least helpful in their position. 
The majority of the public workers interviewed (77\%) were dissatisfied with their public work wages, but all of them would consider the amount to be acceptable if the minimum wage was appropriate. The money earned, not called monthly income, often covered the family's expenditures, but often remained below it.

According to our study, $78 \%$ of physical work is carried out mainly by those involved in the public work programme in the communal area. Most non-profit workers have performed semi-skilled jobs (68\%), and they have a primary school certificate. But graduates with tertiary education also appeared at all levels of activity.

The respondents' opinion on the work done is mostly homogeneous: they believe that their work is measurable and has tangible results. The members of the sample stated that they gained new knowledge on employment, which they can use in their daily lives, feel good at their workplace, and most of them would offer it to their friends. According to them, it fills them with satisfaction that they contribute to the beauty of their environment.

Many respondents thought it was unimaginable to work in public, because it meant street sweeping, which they thought was a shame. At that time, they refused the job offered, taking the penalty to lose their 22,800 forints for a year. However, those who had the opportunity to get into municipal institutions were very proud of the environment, what kind of „responsible” jobs they could work as cleaners or office assistants. Since public work has expanded with national employers, the number of job opportunities has increased several times. They give a lot more freedom to employees with other benefits like working in larger groups, outside public and settlement boundaries, working in nature, much looser, with less supervision. The number of „confidential” jobs has increased.

A large proportion of the respondents feel good in the community they work in. Though the decisive part of the work is forced to work, but in the meantime, they realize that it is good to belong to a community, there are no unfulfilled requirements, and it is often time-consuming. If they have not been working for a long time, they are very afraid of constraints, and will only choose to keep the job or to work on the 30-day commitment. Those who are a bit more demanding and realistic will soon realize that it is not so bad for them, and they also know that the demands of factories that promise good earnings are unfortunately not in line with their qualifications, experience, precision, and attitude to work. They either experience it on their own because they have tried or heard from friends.

Public workers are happy to experience changes in their everyday lives. The respondents believed that the financial situation of their families improved somewhat, so they would like to recommend the possibility of public work to others. Many families are now able to pay off their accumulated debt and provide them with regular income, regardless of the low wages. Unfortunately, the existence of a monthly fixed income for many of them means that the repayment of accumulated 
debts can begin. Previously, casual and black work was unpredictable, and it was not possible to be eligible for the family tax allowance.

Others work in flexitime, which is also beneficial for the family because they are better able to help each other in solving everyday problems. There were female respondents who said that she could only take the job where she could cook in the morning and look at it during the day. In their culture, serving the family is a primary concern, and few people can do it with multiple shifts.

Individuals have achieved success through the activity they have done. Participants have reported good-spirited communities, and it is not uncommon to have friends or love relationships. They see success in creating a network of relationships, in shaping the agenda, in developing a sense of usefulness provided by work, in raising family income, and thereby increasing the status of family support.

Several people stressed that it is better to work for themselves and for each other than to stand in front of the post offices for the dole and to "get organised" by work. They notice how serious-minded workers can influence others. They have an agenda, they will have a task, most of them dare not drink alcohol during the day because they are afraid to lose everything. Many people highlight the task they are entrusted with and are happy to trust them to work with people who speak with respect to them as their superiors.

The following conclusions were drawn from the questionnaire survey with public workers:

- 3-4 suitable public work of clients have a strong 'sticking' effect. As a result of a personal interview with several interviewees during the study, they found that they were left in the cycle because they had no time to look for a job. The study found that unemployed people who had been part of a public service job only once were more likely to reintegrate than those who repeatedly did. Presumably, after 5-6 times more public work, there will be little chance of open labour market employment.

- We see a stronger "transition effect” than young people under the age of 25 than the older age group. The effect of the programme is therefore significantly correlated with age. Young people under 25 years of age in public work trusted in the open labour market, while those over 26 years of age are more likely to imagine multiple participation in public work. The older the individual, the greater the resignation to public work that replaces open labour market employment.

- The nature of work in public employment is mostly physical work without qualifications. Despite the low prestige, the work done after a while enhances the individual's self-esteem and sense of utility.

- Most of the participants see the impact of public work on changes in their working knowledge and financial situation. 
- The majority of public workers work in jobs where everyone, or almost everyone, works in public.

- Employers participating in the programme were, for the most part, the mayor's offices, who had been employing workers for many years. The activities they carried out were of a public nature, and the business sector had little interest and would not have been realized in the absence of support.

- The social policy nature of public work is gaining momentum, as decisionmakers have tried to restrict those who would not have been able to work without it.

\section{Conclusion}

Overall, the opinion of international evaluators is that public work programmes

(a) may be a means of combatting poverty by providing temporary employment, if they are targeted at disadvantaged areas or specific labour market groups (Subbarao et al., 2013; Ninno et al., 2009; Martín-Antón et al., 2017; Bertrand, 2017);

(b) but this effect mainly occurs in the short term and only if the public worker wages remain below the minimum wage (Murgai et al., 2015, Datta-Chakrabarti, 2016);

(c) however, public work programmes are not regarded as an active labour market programmes to increase labour market opportunities and reintegrate (Zimmermann, 2012; Norton, 2018);

(d) however, they are also quite expensive (Lal et al., 2010; Azam et al., 2013).

Until 2008-2010, several Hungarian researches (primarily under the leadership of Mária Frey) analysed the labour market and the social impacts of public work. In the course of the investigations, several negative aspects were expressed about the support. Some of the criticisms point out that

(a) subsidized work does not contribute or contributes little to the continued employment of the supported worker in the labour market through work experience, although this objective has been formulated as a function of the instrument;

(b) the local governments primarily use the asset as a source of additional funding for their tasks;

(c) the probability of getting outside the system from public work is smaller than that of other programmes, and the more people will be employed by the public, the less likely it is to get out of the system (later analyses by Cseres-Gergely and Molnár (2014)). 
The two-decade long primary examination focused on examining the composition of public workers in the Hatvan area in 2004, comparing it with the data from the 1994 survey, and completing the 2014 survey with a personal interview in 2017.

The results have shown that the initiative is good and forward-looking, but the experience so far suggests that there are many flaws and „diseases” that need to be improved. Here we have to mention wages, the need for a related training system, or the problems of work tasks, work organization, working conditions.

At the same time, it is well known that there are regions and groups of workers whose employment difficulties and livelihoods in the current economic circumstances may not lack public work. A significant proportion of public workers are those who are not permanently unemployed, who are not already at an acceptable level of performance, in most cases they do not have the expertise, so market players would not be interested in anyway.

At the time of the survey, most of the opinions were drafted that do not dispute the success of the programmes. Outsiders think about it differently, they formulate more criticism. The participants in the test sample measure their negative and positive experiences with their daily work for their own individual goals, and overall, they are satisfied while the researchers set long-term macroeconomic goals.

Based on the results, some concrete recommendations will be made. The development of the public work system would be conditional on the choice of a wide range of activities, the adjustment of remuneration to performance and the combination of different forms of employment (full-time, part-time, engagement, voluntary work). Public work, job creation and training could be used to solve the employment difficulties of municipalities.

The ultimate goal for the future is to avoid „sticking” to public work, which should be supported with targeted assistance, practical training and retraining, which would help to channel jobseekers back to the labour market. Real change can only be achieved by meticulous work and with an approach not seen so far in domestic policy.

\section{References}

[1.] Azam, M., Ferré, C., \& Ajwad, M. I. (2013): Can public works programs mitigate the impact of crises in Europe? The case of Latvia. IZA Journal of European Labor Studies, 2 (1), 10. p.

[2.] Bertrand, M., Crépon, B., Marguerie, A., Premand, P. (2017): Contemporaneous and Post-Program Impacts of a Public Works Program. 57. p. 
[3.] Bujdosó Z - Remenyik B. (2008): A hazai turisták életminőségének a feltérképezése az Észak-Magyarország Régióban. In: Dávid, L (szerk.): A turizmus szerepe az Észak-Magyarország Régióban I-II. Gyöngyös, Magyarország: Károly Róbert Főiskola, pp. 40-48. , 9 p.

[4.] Crost, B. (2016): Can workfare programs offset the negative effect of unemployment on subjective well-being? Economics Letters, 140, pp. 42-47.

[5.] Czibere I. - Molnár E. (2017): Labour market perspectives of young women living in extreme poverty in closed rural space: the case of a HungarianRomanian cul-de-sac border village. Ager. Revista de Estudiossobre Despoblación y Desarrollo Rural. 23. pp. 7-26.

[6.] Czirfusz M. (2014). Az egyenlőtlen földrajzi fejlődés és a magyarországi közmunka. In: Munkaeröpiaci tükör, 2014. MTA Közgazdaság- és Regionális Tudományi Kutatóközpont Közgazdaság-tudományi Intézet, Budapest, pp. 325-327.

[7.] Csehné Papp I. (2007): A közhasznú foglalkoztatás jogi és humán vonatkozású változásai az utóbbi tíz évben. Munkaügyi Szemle. 4. pp. 15-19.

[8.] Cseres-Gergely Zs., Molnár Gy. (2014): Munkapiaci helyzet a közfoglalkoztatásból való kilépés után. In: Munkaeröpiaci tükör, 2014. MTA Közgazdaság- és Regionális Tudományi Kutatóközpont Közgazdaságtudományi Intézet, Budapest, pp.143-153.

[9.] Datta, P., Chakrabarti, S. (2016): Gains from short-term public works: A review of performance of MGNREGA in Tripura. The NEHU Journal. 1. pp. 57-77.

[10.] Douarin, E., Mickiewicz, T. (2017): Unemployment and Labour Market Policies. In: Economics of Institutional Change. pp. 205-226.

[11.] Eardley, T., Bradshaw, J., Ditch, J., Gough, I. és Whiteford, P. (1996): Social Assistance schemes in the OECD countries. Volume 1. Synthesis report, DSS Research Report 46. London: HMSO. 208 p.

[12.] Fazekas K. (2015): Közfoglalkoztatás, foglalkoztatáspolitika, gazdasági növekedés. In: A közfoglalkoztatás aktuális kihivásai - javasolt fejlesztési irányok. 2015.11.25, Budapest. pp. 8-11.

[13.] Frey M. (1993): A közhasznú foglalkoztatás munkaerő-piaci hatásai. Munkaügyi Szemle, 5. pp. 30. 
[14.] Frey M. (1995): A közhasznú foglalkoztatás munkaerőpiaci hatásai: Egy empirikus kutatás tanulságai. In: A jövő munkahelyeiért [1. köt.]. Bp.: Struktúra-Munkaügy, 1995.pp. 132-147.

[15.] Frey M. (1997): Helyi foglalkoztatási kezdeményezések, alternatív munkaerőpiac: Hazai helyzetkép. In: A non-profit szervezetek szerepe a helyi foglalkoztatásban. Bp.: Hálózat a Demokráciáért, 1997. pp. 159-201.

[16.] Frey M. (2007): A közhasznú foglalkoztatás munkaeröpiaci hatásai. http:// old.ektf.hu/ juhasz.istvan/human_erof_akt_k/Munkaer\%f5piaci\%20 t\%fck\%f6r/2007/frey.pdf. Accesssed 01 December 2017

[17.] Grover, C., Stewart, J. (1999): Market workfare: Social Security, social regulation and competitiveness in the 1990s'. Journal of Social Policy, vol. 28, 1, pp. 73-96.

[18.] Guccio, C., Pignataro, G., Rizzo, I. (2014): Do local governments do it better? Analysis of time performance in the execution of public works. European Journal of Political Economy, 34, pp. 237-252.

[19.] Herdon, M., Zörög Z. (2012): The perceptions of agricultural graduates on the correlation of their labour market situation and qualification. Hungary Journal of Ecoagritourism 8:2 pp. 326-331 6p. (2012)

[20.] Hort, S. (2001): Sweden-still a civilized version of workfare activating the unemployed, a comparative appraisal of work-oriented policies. New Brunswick, Transaction Publishers, pp. 243-266.

[21.] Ismail, M. A. (2016): Globalization and new international public works agreements in developing countries: an analytical perspective. Routledge. 316. p.

[22.] Karimi, Z. (2018): Public Works Programs as a Strong Means for Land and Water Conservation in Iran. In: Full Employment and Social Justice. pp. 109-138.

[23.] Kim, T. K., Zurlo, K. A. (2007): Factors that influence workfare program participants: focusing on South Korea's Self-Sufficiency Program. Int'l Soc. Work, 50, 796. p.

[24.] Ko, H., Cho, H. (2017): Revisiting the effectiveness of the employmentoriented welfare state: Considering the quality of employment achievement. Asian Social Work and Policy Review, 11 (2), pp. 158-167.

[25.] Koltai L. (2014): A közfoglalkoztatottak jellemzői. Munkaügyi Szemle 3. pp. 60-69. 
[26.] Koós B. (2016): Közfoglalkoztatás a mezőgazdaságban. Tér és Társadalom 3. pp. 40-62.

[27.] Kulinyi (2013): A közfoglalkoztatás változó céljai. Munkaügyi Szemle 1. pp. 17-26.

[28.] Lal, R., Miller, S., Lieuw-Kie-Song, M., Kostzer, D. (2010): Public works and employment programmes: Towards a long-term development approach (No. 66). Working Paper, International Policy Centre for Inclusive Growth. 73 p.

[29.] László Gy. (2016): A hátrányos helyzetűek foglalkoztatási nehézségei. Opus et Educatio, 3 (3). pp. 264-276.

[30.] Martín-Antón, M., Negro, V., del Campo, J. M., López-Gutiérrez, J. S., Esteban, M. D. (2017): The Gigantism of Public Works in China in the Twenty-First Century. Sustainability, 9(9), 1581. p.

[31.] Melo, J. J. D. (2009).: Public works policy in Portugal: a case study in unsustainability. $13 \mathrm{p}$.

[32.] Murgai, R., Ravallion, M., \& van de Walle, D. (2015): Is workfare costeffective against poverty in a poor labor-surplus economy? The World Bank Economic Review, 30(3), pp. 413-445.

[33.] Ninno, C. D., Subbarao, K., Milazzo, A. (2009): How to Make Public Works Work: A review of the experiences (No. 48567). The World Bank. 93 p.

[34.] Norton, T. R. (2018): Lessons Learned in Disaster Debris Management of the 2011 Great East Japan Earthquake and Tsunami. The 2011 Japan Earthquake and Tsunami: Reconstruction and Restoration. pp. 67-88.

[35.] Robbins, B. (2015): Public Works. University of Edinburgh Postgraduate Journal of Culture of the Arts, (21).

[36.] Rosas, N., Sabarwal, S. (2016): Public Works as a Productive Safety Net in a Post-Conflict Setting. 33 p.

[37.] Scharle Á. (2013): A közfoglalkoztatás mérete és költsége. In: Munkaeröpiaci tükör, 2013. MTA Közgazdaság- és Regionális Tudományi Kutatóközpont Közgazdaság-tudományi Intézet, Budapest, pp. 61-62.

[38.] Schöb, R., Knabe, A., \& Weimann, J. (2016): The subjective well-being of workfare participants: Insights from a Day Reconstruction Survey. pp. 1311-1325.

[39.] Shah, M., Steinberg, B. M. (2015): Workfare and Human Capital Investment: Evidence from India (No. w21543). National Bureau of Economic Research. 38. p. 
[40.] Subbarao, K. et. al (2013): Public Works as a Safety Net. The World Bank, Washington D.C., 430 p.

[41.] Szűcs Cs. - Zörög Z. - Csomós T. (2013): Career Tracking of Agricultural Graduates in Hungary. Annals of The Polish Association of Agricultural and Agribusiness Economists XV. pp. 409-415. , 7 p. (2013)

[42.] Uszkai A. (2014): Innováció és oktatás az élhetőbb vidékért. A Falu, 29 (2), pp. 75-85.

[43.] Váradi M. (2016): Értékteremtő közfoglalkoztatás periferikus vidéki terekben. Esély 1. pp. 30-57.

[44.] Váradi M. (2010): A közfoglalkoztatás útjai és útvesztői egy aprófalvas kistérségben. Esély. 1. pp.79-99.

[45.] Zieliński, M. (2015): Unemployment and labor market policy in Visegrad Group countries. Equilibrium. Quarterly Journal of Economics and Economic Policy,10 (3), pp. 185-201.

[46.] Zimmermann, L. (2012): Labor market impacts of a large-scale public works program: evidence from the Indian Employment Guarantee Scheme. https:// papers.ssrn.com/sol3/papers.cfm?abstract_id=2158000\#\#. Accessed 01 December 2017

\section{Authors}

\section{Dr. habil Imola Cseh Papp, PhD}

associate professor

Eötvös Loránd University

Faculty of Education and Psychology

Institute of Adult Training-Research and Knowledge Management

papp.imola@ppk.elte.hu

\section{Dr. Erika Varga, PhD}

associate professor

Szent István University

Faculty of Economics and Social Sciences

varga.erika@gtk.szie.hu 